\title{
Solitary Plasmacytoma of the Frontal Bone
}

\author{
Betul Cengız Peker, Zeki Serdar Ataızı, Zühtü Ozbek ${ }^{3}$ \\ Department of Pathology, Yunus Emre State Hospital, Eskişehir, Turkey \\ Department of Neurosurgery, ${ }^{2}$ Yunus Emre State Hospital, Eskişehir, Turkey \\ Department of Neurosurgery, ${ }^{3}$ Eskisehir Osmangazi University, Faculty of Medicine, Eskişehir, Turkey
}

Extramedullary plasmacytoma and solitary plasmacytoma are localized neoplasms. Solitary plasmacytoma of bone consists about $4 \%$ of malignant plasma cell tumors. A plasmacytoma involving the frontal bone is unusual, and a limited number of cases have been reported. We present a rare case of a solitary plasmacytoma of the frontal bone manifesting as a forehead lump.

Key Words : Extramedullary · Plasmacytoma · Frontal bone.

\section{INTRODUCTION}

Plasma cell tumors may manifest in three different pathological entities : multiple myeloma, extramedullary plasmacytoma and solitary bone plasmacytoma ${ }^{2-4)}$. Although multiple myeloma is a systemic disease, extramedullary plasmacytoma and solitary plasmacytoma are localized neoplasms. Extramedullary plasmacytoma occurs in extraosseous sites ${ }^{19}$. Plasmacytoma is generally localized in bone or soft tissue and presents with mass effect, pain, and infiltrative behavior ${ }^{6,16)}$.

A plasmacytoma involving the frontal bone is unusual, and a limited number of cases have been reported in the literature. In this paper, a case of solitary plasmacytoma of the frontal bone presenting with a forehead lump was described, along with a review of the relevant literature.

\section{CASE REPORT}

A 68-year-old female patient was admitted to the neurosurgical department's inpatient clinic with chronic headache and rapidly progressive painful protruding mass on her head. Physical examination revealed a tender, $11 \times 9 \mathrm{~cm}$ mass on the right frontal region of the skull. Her cranial nerve examination was normal. The skull survey showed large lytic changes in the frontal bone. Magnetic resonance imaging (MRI) of the head showed an extra-axial mass which was presumed to be a meningioma (Fig. 1). MRI angiography showed bilateral shift of the anterior cerebral arteries due to tumor mass. A frontal craniotomy was performed and the tumor was sub-totally removed. The mass was soft, highly vascular with a poorly defined border on the bone. The tumor mass was found to be attached to the dura with no intraparencymal spreading. The dura was intact at the time of operation.

After removal, tumor tissue was fixed in $10 \%$ formalin so-

- Received : May 27, 2015 • Revised : February 27, 2016 •Accepted : September 10, 2016

- Address for reprints : Betul Cengız Peker

Department of Pathology, Yunus Emre State Hospital, Uluönder mah. Fevzi Çakmak cad. No:1, Eskişehir 26190, Turkey

Tel : +90-5055978868, Fax : +90-2223352041, E-mail : betip76@yahoo.com, ORCID : https://orcid.org/0000-0002-2503-7446

This is an Open Access article distributed under the terms of the Creative Commons Attribution Non-Commercial License (http://creativecommons.org/licenses/by-nc/4.0) which permits unrestricted non-commercial use, distribution, and reproduction in any medium, provided the original work is properly cited. 
lution, and dehydration was applied with graded alcohols and all of the specimen was embedded into paraffin. Hematoxylin-eosin stained sections of tumor revealed a monomorphous appearance of plasma cells with characteristic round-oval cells, eccentric nuclei, and abundant cytoplasm (Fig. 2). Immunohistochemical staining was conducted on the Ventana BenchMark XT (Roche Diagnostics, Basel, Switzerland) automated slide stainer. The tumor cells were positive for $\kappa$-chain, CD138 and CD38. However, they were negative for cytokeratin, CD45, CD20, $\lambda$-chain, and CD3, revealing a pathological diagnosis of plasmacytoma.

The systemic evaluation required to make the diagnosis of solitary plasmacytoma included routine blood tests, serum calcium level and serum immunoglobulin levels, which were all normal. No Bence-Jones protein was detected in the urine. Bone marrow aspirate was unremarkable with normal morphological appearance and no bone marrow plasmacytosis. Computed tomography scan of the chest and abdomen showed no evidence of disease. A skeletal survey revealed no evidence of other bone lesions and bone scintigraphy showed

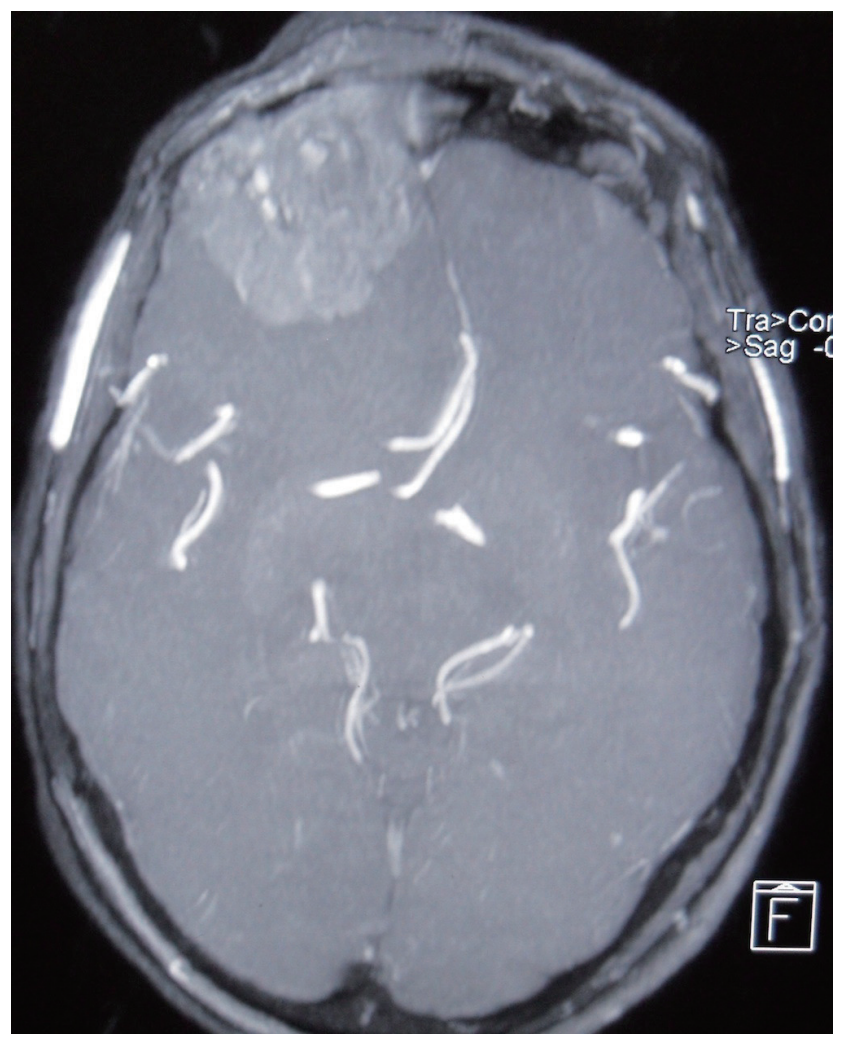

Fig. 1. Magnetic resonance imaging of the head showing an extra-axial mass. that only the frontal bone was infiltrated by tumor.

Post-operative MRI showed eliminated midline shift and sub-totally removed tumor mass. The patient refused postoperative irradiation and systemic chemotherapy and was discharged. Four months later, she was re-admitted to our clinic with frontal swelling; MRI showed the re-growth of the previous mass. A new bone marrow biopsy showed no evidence of systemic disease and the skeletal survey was still negative for other lesions. The patient is alive and without any systemic dissemination of disease after 14 months.

\section{DISCUSSION}

Solitary plasmacytoma of bone consists about $5 \%$ of the malignant plasma cell tumors ${ }^{8)}$. The spine, pelvis, and femur are the most common sites of involvement. However, the skull is a rare location for solitary plasmacytoma without signs of systemic myelomatosis ${ }^{17}$. Solitary craniocerebral plasmacytoma manifests in two forms : primary plasmacytomas arising from the skull and intracranial extramedullary plasmacytomas arising from the dura and the brain ${ }^{10,15)}$. In order to diagnose solitary plasmacytoma, multiple myeloma must be ruld out, and the required systemic evaluation should include a skeletal survey, bone marrow aspirate, serum and urine protein electrophoresis and quantitative immunoglobulins.

Solitary plasmacytoma may occur at any age, but is mostly

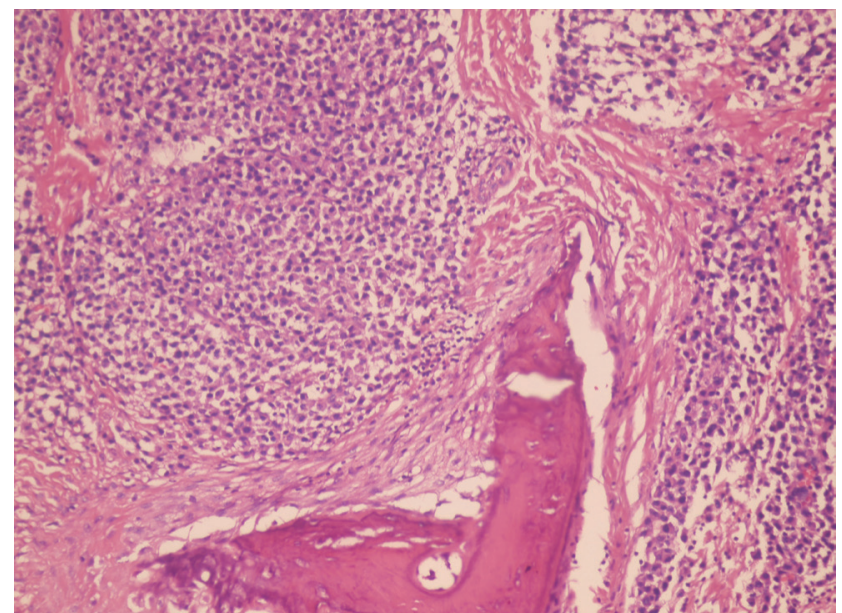

Fig. 2. The tumor is composed of a mass of monomorphous plasma cells with the characteristic round-oval shape, eccentric nuclei, and abundant eosinophilic to amphophilic cytoplasm (hematoxylin and eosin stain, orginal magnification $\times 100$ ). 
seen in patients in their fifties or sixties ${ }^{7,16,19)}$. A complete blood count, complete metabolic profile and urinalysis with no abnormalities should be obtained. Clinical symptoms and signs are variable, non-specific and largely depend upon the location of tumor. The neurological abnormalities in patients with plasma cell neoplasms originating from the skull or dura are usually due to increased intracranial pressure and include headache, nausea, vomiting, along with visual disturbances ${ }^{19)}$. Therefore, solitary craniocerebral plasmacytoma is often misdiagnosed pre-operatively. The differential diagnosis of the craniocerebral plasmacytoma includes meningioma, metastasis, lymphoma, osteochondroma, infectious meningitis and sarcoma ${ }^{3)}$. Establishing the diagnosis of plasmacytoma requires a biopsy. Solitary plasmacytoma should be histologically distinguished from plasma cell granuloma. The plasma cell granuloma is characterized immunohistochemically by a polyclonal plasma-cell proliferation ${ }^{5,20)}$.

The etiology of plasmacytoma remains unclear. However, viral infections and trauma are thought to be involved in the etiology. Hepatitis C and Epstein-Barr viruses are possible viral agents influencing the development of plasmacytoma ${ }^{11}$. Our case had a history of head trauma about 10 years ago. A study by Pasch et al. ${ }^{14)}$ showed the possible role of previous trauma in plasmacytoma.

Surgical intervention is an excellent primary treatment option of solitary craniocerebral plasmacytoma. Arienta et al. ${ }^{1)}$ have reported that additional treatment is needed after the surgery. However (?), Jakubowski et al. ${ }^{12)}$ reported that radiotherapy is the most successful treatment after the surgery. Du Preez and Branca ${ }^{10)}$ reported that radiotherapy should be given only in cases with local recurrence. The cure rate has been suggested to be higher when radiotherapy (pre- or post-operative) was used together with surgical excision ${ }^{3,10,17)}$. Our patient showed a recurrence 4 months after the initial diagnosis. We believe that the patient's refusal to radiotherapy-chemotherapy treatment may be effective on early recurrence of this tumor.

Solitary plasmacytoma of the bone tends to disseminate or progress to multiple myeloma over a period of $7-23$ years ${ }^{9,13,18}$. Therefore, it should be kept in mind that solitary plasmacytoma may progress to multiple myeloma and strict follow-up of solitary plasmacytoma patients is of paramount importance.

\section{CONFLICTS OF INTEREST}

No potential conflict of interest relevant to this article was reported.

\section{INFORMED CONSENT}

Informed consent was obtained from all individual participants included in this study.

\section{AUTHOR CONTRIBUTIONS}

\author{
Conceptualization : BCP, ZSA, ZO \\ Data curation : BCP, ZSA, ZO \\ Formal analysis : BCP, ZSA, ZO \\ Funding acquisition : BCP, ZSA, ZO \\ Methodology : BCP, ZSA, ZO \\ Project administration : $\mathrm{BCP}, \mathrm{ZSA}, \mathrm{ZO}$ \\ Visualization : BCP, ZSA, ZO \\ Writing - original draft : $\mathrm{BCP}, \mathrm{ZSA}, \mathrm{ZO}$ \\ Writing - review \& editing : BCP, ZSA, ZO
}

\section{ORCID}

Betul Cengiz Peker https://orcid.org/0000-0002-2503-7446

Zeki Serdar Ata1zı https://orcid.org/0000-0001-5960-3082

Zühtü Ozbek https://orcid.org/0000-0003-0028-4181

\section{References}

1. Arienta C, Caroli M, Ceretti L, Villani R : Solitary plasmacytoma of the calvarium: two cases treated by operation alone. Neurosurgery 21 : 560-563, 1987

2. Benli $K$, Inci S : Solitary dural plasmacytoma: case report. Neurosurgery 36 : 1206-1209, 1995

3. Bindal AK, Bindal RK, Van Loveren $H$, Sawaya $R$ : Management of intracranial plasmacytoma. J Neurosurg 83 : 218-221, 1995

4. Cakir E, Karaarslan G, Usul H, Baykal S, Arslan E : Solitary plasmacytoma with intracranial intraorbital and, paranasal sinus extension. J Clin Neurosci $10: 266-268,2003$

5. Cannella DM, Prezyna AP, Kapp JP : Primary intracranial plasma-cell granuloma. Case report. J Neurosurg 69 : 785-788, 1988 
6. Cerase A, Tarantino A, Gozzetti A, Muccio CF, Gennari P, Monti L, et al. : Intracranial involvement in plasmacytomas and multiple myeloma: a pictorial essay. Neuroradiology 50 : 665-674, 2008

7. Chiang SK, Canalis RF, Ishiyama A, Eversole LR, Becker DP : Plasmacytoma of the temporal bone. Am J Otolaryngol 19 : 267-273, 1998

8. Conklin R, Alexanian R : Clinical classification of plasma cell myeloma. Arch Intern Med 135 : 139-143, 1975

9. Corwin J, Lindberg RD : Solitary plasmacytoma of bone vs. extramedullary plasmacytoma and their relationship to multiple myeloma. Cancer 43 : 1007-1013, 1979.

10. Du Preez JH, Branca EP : Plasmacytoma of the skull: case reports. Neurosurgery $29:$ 902-906, 1991

11. Jacob PM, Nair RA, Koshy SM, Kattoor J : Solitary plasmacytoma of the metacarpal bone in an adolescent. Indian J Pathol Microbiol 57 : 323-325, 2014

12. Jakubowski J, Kendall BE, Symon $L$ : Primary plasmocytomas of the cranial vault. Acta Neurochir (Wien) 55 : 117-134, 1980

13. Matsuda M, Nakazawa T, Kizuki H, Matsumura K, Nakasu S, Handa J : Solitary plasmacytoma of the skull vault--case report. Neurol Med Chir (Tokyo) 36 : 388-392, 1996
14. Pasch W, Zhao X, Rezk SA : Solitary plasmacytoma of the bone involving young individuals, is there a role for preceding trauma? Int J Clin Exp Pathol 5 : 463-467, 2012

15. Provenzale JM, Schaefer P, Traweek ST, Ferry J, Moore JO, Friedman AH, et al. : Craniocerebral plasmacytoma: MR features. AJNR Am J Neuroradiol $18:$ 389-392, 1997

16. Rahmah N, Brotoarianto $H$, Andor $E$, Kusnarto G, Muttaqin Z, Hongo K : Dural plasmacytoma mimicking meningioma in a young patient with multiple myeloma. Biomed Imaging Interv J 5 : e5, 2009

17. Tanaka M, Shibui S, Nomura K, Nakanishi $Y$ : Solitary plasmacytoma of the skull: a case report. Jpn J Clin Oncol 28 : 626-630, 1998

18. Tong D, Griffin TW, Laramore GE, Kurtz JM, Russell AH, Groudine MT, et al. : Solitary plasmacytoma of bone and soft tissues. Radiology 135 : 195-198, 1980

19. Vujovic O, Fisher BJ, Munoz DG : Solitary intracranial plasmacytoma: case report and review of management. J Neurooncol $39: 47-50$, 1998

20. West SG, Pittman DL, Coggin JT : Intracranial plasma cell granuloma. Cancer $46: 330-335,1980$ 